\title{
THE EROSION OF TRUST - A REFLECTION
}

David Gumbrell in conversation with BJE's deputy editor Mark Deacon

\section{INTRODUCTION}

David Gumbrell was a Primary headteacher in a successful London school when Michael Gove was Education Secretary. He is now a successful writer, trainer and academic with a special interest in teacher induction, development and wellbeing. The following are some of his reflections from the position of school leadership on what he sees as fundamental flaws in Gove's leadership of education. Whilst, Gumbrell remains aware of potential unconscious bias he uses trust as the pivot, for his reflections. He states 'I hope to mitigate the inevitable emotional attachment to my profession and my view as to the effect that Michael Gove has had upon it, both at the time and also the resultant legacy of his ministerial post.

Gove was and remains a polarising figure. For some Gove was the saviour of high-quality education, others regarded him as a 'vandal', busy sacking the personcentred education which had built up and refined since Plowden. Although never a consensus view, many teacher expressed their dismay at the reforms to the accreditation structure, curriculum, schemes of assessment and opportunities to control schools brought in by Gove.

\section{THE INTERVIEW}

It's easy to throw stones at politicians, lets start positively. Where do you see a positive legacy for Gove?

For many, his vestige will be that he was the minister who pushed through Pupil Premium funding and increased the autonomy of schools. Passionate about both of these aims, he drove these policies forward and I am sure that many benefited from the financial rewards, or greater powers afforded to those who followed his lead.

\section{And yet you have serious reservations about his time in office?}

For others, the reality is somewhat different. Echo chambers of consultation, in pursuit of the notoriety of moving at pace, Gove appears to have inadvertently alienated the people that he needed most, the teachers on the chalk face. He appeared to this audience, to not listen to Headteachers and instead was lured by the next headline, possibly realigning himself to the profession which he had before his time of office, journalism. 


\section{How would you examine Gove's tenure as Education Secretary?}

Through the lens of trust, it appears that the speed of change was just too great and yet trust relationships take time.

Michael Gove himself stated 'The pace of change in our education system recently has been fast and the reaction at times furious'. In saying this, he must have realised that he wasn't able to attain the traction for his policies that he would have wished for. Despite this, he seemingly remained reticent to amend them, and so professional views were becoming ever more polarised.

Speed and trust are two words that are juxtaposed here and could be why Gove was sacked so close to an election by the then Prime Minister, David Cameron. In summarising his legacy, Alex Forsyth, BBC Correspondent, finished her report saying 'With less than a year until the General election, there is no doubt it takes having someone less controversial in charge of education, will help win back some support, not least from teachers'. A sad indictment from the personal friend and boss that David Cameron was, yet history shows that sometimes politics is quite brutal.

\section{Controversial, or just not trusted?}

It is possible that Michael Gove, in his desire to make his swift changes to policy, policies that I am sure were well intended, did not have the impact that he would have wanted. Instead, they divided the very people that he wanted to bring along with him.

We have to remember that in June 2010 a General Election year, Gove addressed an audience at the National College Annual Conference where he stated

I am, frankly, impatient for us all, as a nation, to do better. In the relentless drive to help every child achieve everything of which they are capable there can be neither rest nor tranquillity.

In that urgency, Gove appeared to not do the necessary groundwork to build a platform of trust first. Perhaps it was the lack of a bedrock, there could only be one outcome, namely, his replacement as the next Education Secretary, by Nicky Morgan in 2014.

\section{Could you explain what you mean by "Build trust?"}

Andrea Bonior Ph.D., in Psychology Today, outlines 7 ways to build trust:

1. Say what you mean and mean what you say.

2. Be vulnerable - gradually.

3. Remember the role of respect. 
4. Give the benefit of the doubt.

5. Express your feelings functionally, especially when it's tough.

6. Take a risk together.

7. Be willing to give as well as receive.

Looking at each of these, it becomes increasingly obvious that the hard work of these foundations may have been flouted, assumed to just be there, or simply not invested in heavily enough in the infancy of the coalition and with the Headteachers and teachers within the education workforce.

Michael Gove in my view failed to surround himself with people who would temper his enthusiasm, widen his experiences and challenge the notion that all schools needed to be academies or free schools. He seemed at times to almost relish the moments when he played the pantomime villain and yet failed to realise that a demotivated workforce would not deliver the academic standards that he had set his career on achieving.

He certainly said what he meant to say and meant what he said. Russell Hobby was reported by the BBC stating 'Michael Gove had a radical and sincere vision for transforming education, but he largely failed to bring the profession with him'.

\section{So what was going on?}

Russell Hobby, then general secretary of the National Association of Head Teachers, was able to see the sincerity of the vision, that Michael Gove was doing what he thought was right for education. However, his vision was constrained, limited and limiting. He sat within an echo-chamber of fellow educationists who would reinforce his decisions as truths, back his vision as accurate and thus proceeded into the public domain with that eschewed belief that he was right to proceed. However, this stance is counter to many of the seven principles of trust.

At his right-hand side was Dominic Cummings. In the background, he would encourage Michael Gove to take a hard line, to show no signs of weakness to his coalition partner, David Laws, nor to the Unions. It was a defence mechanism combined with a need to push through the educational dream that he had been harnessing and honing in his days as Shadow Secretary and as a Times journalist. He was quick to throw arrows at the Government at that time and yet he wanted to now protect himself from the volley of verbal assaults that were now firmly aimed in his direction.

\section{Do you think Michael Gove ever made himself vulnerable?}

Secondly, Michael Gove and the word vulnerability appear to be mutually exclusive words in terms of his leadership style. In his urgency to set out a plan and deliver it within the four years of office he just dictated the future, laid down his 
ambition plan and deafened himself to any objectors. His tenacity is commendable, his ability to furrow his ploughed line admirable, yet his chance to bring others with him was missed. He may have been better placed to show authentic vulnerability, rather than wield power and might.

\section{Giving and receiving respect is an important characteristic of a good leader.} Respect is something that Gove craved, certainly amongst his professional peers. He aimed to garner the respect of the populous for his transformational education legacy. However, respect is a two-way street. Michael wanted it, but rarely, if ever, gave it. Labelling teachers with belittling phrases that may have made a journalist's headline, a fellow MP guffaw, made teachers seeth. Feeling threatened by the teaching unions, he used nebulous name-calling, more befitting to a playground spat, as his language to engender respect.

I am always impressed with what Mick Waters (2013) comment:

'Gove had the capacity to hit the media with generalised insults about the profession and, unsurprisingly those are what many teachers heard. To think they were seen as 'enemies of promise' or 'dealers in despair' or 'whingers' upset hard-working teachers'.

\section{Do you believe that the environment Gove created had an impact on teachers?}

This is going to take some explaining. Ruthless facts and cold hard data and a tighter framework of inspection and performance related pay are difficult to balance with the fourth tenet of Bonior's trust relationship model, giving the benefit of the doubt. Offering flexibility and the benefit of the doubt was seemingly eradicated and superseded with ruthless accountability measures in its place. The curriculum was tighter, money was tighter, time was tighter during the tenancy of Michael Gove. With so much at stake, inevitably teachers had to become ever more compliant to achieve their pay rise or for the school to get the next Ofsted grade. However, with less autonomy, teachers started to resign. With no flex in the system, teachers started to break. With Mr Gove's no-nonsense policy, the recruitment crisis in the education system began. In a briefing paper entitled Teacher Recruitment and Retention in England (2019), published to the House of Parliament, stated:

The number of reported full-time teacher vacancies in state-funded schools has risen, from 389 (0.1\% of the workforce) in 2010 to 987 (0.3\%) in 2018. The number of temporarily filled positions increased from 1,791 (0.5\% of the workforce) to 2,777 (0.8\%) over the same period. 
This data would suggest that, during Mr Gove's tenure 2010-2014 (and in the subsequent 4 years) just over 1000 more classes have temporary teachers in front of them, with a further 600 classes with no teacher at all. This reduction in quality trained staff continues into 2020 with subsequent Education Secretaries failing to stem the flow. They too, seemingly beset on pursuing privatisation rather than building the trust of the profession at large.

\section{Gove spoke a lot about trusting teachers, releasing them to teach and innovate.}

Let me give you a typical example. In May 2013, Michael Gove attended the NAHT conference in Birmingham. His audience included members of the biggest union for head teachers, representing $85 \%$ of primary heads and $40 \%$ of secondary heads in England, Wales and Northern Ireland. This was a chance to express his feelings, an opportunity to stand with and alongside education leaders.

'It should be Government's job to help, serve and support you - not direct, patronise and fetter you.' This started to appease. He then went on to express his feelings 'I am passionate about extending the freedoms denied to you by the last government'.

This went some way to pacify. However, he went onto say

'If people find it stressful that I'm demanding higher standards, then I'm not going to stop demanding higher standards'.

This inflammatory phrase did little to recognise, sympathise or empathise with his Head teachers. The earlier words of thanks were forgotten, and the hall erupted. Trust was irrevocably broken and yet Gove responded at the end of the speech, saying to reporters that,

'What I haven't heard over the last hour is a determination to be constructive, critical yes, but not constructive'.

Higher levels of accountability were supplemented with radical GCSE reform. This was most certainly a risk, yet this decision was not taken together with the teaching profession who had to deliver it. Instead of this desirable consultation, Mr Gove offered them the chance to be scrutinised on the outcomes of these new tests or paid according to the proportions of young people who passed the qualification threshold. Many thousands had their school judged by Ofsted as being effective, or ineffective, according to this new, untrialled measure of success. In short, Mr Gove took the risk, but teachers and headteachers bore the brunt of the outcome of his risk. Whilst claiming that this was the vanguard of a new 
future, an opportunity to drive up standards, in the short-term we were comparing apples with pears.

We could see that despite not being comparable in nature, claims and assertions were still being made about them. When the data was poor, Gove claimed it was the quality of teaching; when the data was good, Gove claimed it was academisation that was the reason for that school's success. This selective hand-picking of data did little to make teachers feel that they were in this together, or that they were trusted in their professional judgements by the right honourable Member of Parliament for Surrey Heath. Trust continued to be eroded.

\section{Isn't data a bit of a dark art?}

Absolutely. However we càn bring our critical faculties to bear as well as reply on experts.

Mick Waters (2013) states

Data, often suspect, drove an agenda that relied on inspection outcomes (also suspect), league table position and the ministerial influence and recognition. Because of these drivers, the diet of pupils became distorted as schools chased the pupils on the cusp, offer a range of courses that feed the machine of data, spoon-feed pupils with pulped up learning and spread 'good practice' via a study of what Ofsted might be looking for as their flavour of the month.

Within the 2014 address to think tank Policy Exchange, entitled 'Purpose of Our School Reforms', Gove stated

'Instead of setting to follow a consensus that doesn't agree - and I suspect never will - I have set out to follow the evidence'.

In looking for this evidence, he looked to education systems in Alberta, Calgary and Edmonton in Canada, Sweden, Finland and Singapore. In each he found the evidence that was needed to confirm that he was right, that his pursuit of this version of excellence was correct, that he was on the right path.

You have painted a picture of a doctrinaire Education Secretary to an extent ruthlessly driving his agenda on selective evidence. What was the consequence of this?

In an ideal world there is co-operation, a willingness to give as well as receive. This can build the sense of trust between the two parties so that they can focus on 
growth. Within this ideal, the Scale of Cooperation (2019) outlines that cooperation creates trust and that it is achieved through feedback, consolidation and flow.

The possibilities, should these conditions be achieved, are both endless and desirable. However, the precursor to this condition of co-operating however is Avoiding. Within this middle range, there is a need to move from talking about to talking with. These two gateways lead to 'Struggling' with the former or 'Co-operating' with the latter; Gove chose the former. Instead of recognising the benefits of talking with teachers and headteachers, he chose to talk about teaching and that created distance between himself and the profession and eroded the trust between the two parties as a result. Gove's education revolution was turning into a fight, a conflict based in criticism.

Trust was eroding, co-operation was going to get ever harder.

\section{How long does erosion of trust take?}

We associate erosion with slow processes. Consider the whittled spires of Vermillion Cliffs National Monument, Arizona and rounded the Moeraki Rocks along Koekohe Beach, New Zealand. Each took millions of years to erode, to be shaped into the stunning geological monuments that they are today.

Within four years of office, Gove eroded the trust in the profession through removal of autonomy and control. What was exposed was a leadership style characterised as angular, twisted and sharp. A profession that was broken up into academies and free schools; a profession that remained strong yet felt battered by the elements.

Teacher training had been sped up with the SCITT programme, proposed by the Carter review of Initial Teacher Training; Gove was a man in a hurry, and yet time was not his ally.

\section{Do you ever wonder how Gove might have reflected on his time at Education?}

Gove was seemingly able to learn from this experience. His time as Justice Secretary started with a more open dialogue with people within the profession who could help and guide him. When he was moved again to Environment Secretary, he again took a more discursive approach than he had ever done at the Department for Education. Both portfolios were not his main calling and so he needed to reach out in order to learn more about them. Bennett (2019) states: -

Much like his appointment as Justice Secretary, Gove found himself leading a department to which he had previously given little thought. He emulated his approach at Justice and sought as wide a range of opinions as possible as soon as he sat down at his desk'. 
Cook, chief executive of the Howard League for penal reform stated to Bennett (2019) that

With his track record at Education, we expected an ideologue, but of course he had come into Education with a blueprint. He didn't have a vision of what he wanted to do [with Justice]. He has a moral compass, but not a plan of action.

\section{Do you have a grudging admiration for Michael Gove?}

His political career must have taken its toll with the constant battering and weathering of the storms that he has embroiled himself in. Yet, despite all this he is still standing, and I have a certain admiration in that. He has withstood the attacks, the wave after wave of criticism, the flotsam and jetsam of life on the front bench and yet, he is still a Member of Parliament, a member of Boris Johnson's cabinet government. He is articulate, he is intelligent, he is resilient. However, Michael Gove also suffers from showing a lack of vulnerability, appears to be amiss in terms of emotional intelligence, and had a deficiency in being willing to build trust over time with the Education community. Despite his good intentions, the reality of Gove's educational landscape is not the Vermillion Cliffs, not the Moeraki Rocks, more the Needles, Isle of Wight. Rocky stacks separated and apart. Academies, or not. Outstanding, or not. Ofsted-ready, or not. Erosion, time, trust.

Although political disagreement is a normal part of any functioning democracy and yet our state education system can't run properly if so many of those working in it don't trust those making the decisions.

\footnotetext{
* As an interview references have not been provided. However, they have been checked.
} 